\title{
Effect of previous growth conditions on the starvation-survival of Escherichia coli in seawater
}

\author{
Jorge García-Lara, ${ }^{*}$ Josefina Martínez, Mercè Vilamú and José Vives-Rego \\ Departament de Microbiologia, Universitat de Barcelona, Av. Diagonal 645, 08028-Barcelona, Spain
}

(Received 5 October 1992; revised 4 March 1993; accepted 11 March 1993)

\begin{abstract}
The starvation-survival of Escherichia coli in seawater was assessed by plate and epifluorescence counts, ${ }^{3} \mathrm{H}$-label decrease, cellular DNA concentrations, and metabolic activities. These assays were performed on two types of populations, adapted and non-adapted to seawater. The number of viable cells in the adapted population remained constant throughout starvation-survival in sterile seawater. In contrast, a significant decrease in the ability of the non-adapted $E$. coli to form colonies on plates following starvation-survival in sterile seawater was observed. However, this drop in viable counts was not mirrored by the epifluorescence counts and ${ }^{3} \mathrm{H}$-label, which did not show major changes for either population during the experiments, indicating maintenance of the number of cells. In addition, a significant increase in and subsequent maintenance of DNA content and thymidine incorporation was observed for both populations during starvation-survival in sterile seawater. The changes in cell-attached exoproteolytic activity and electron transport system activity showed that adapted and non-adapted $E$. coli cells maintain their metabolic potential. Cell-free exoproteolytic activity was drastically reduced in both populations. Adapted cells showed higher electron transport system activity and thymidine incorporation than non-adapted cells at the onset of starvation-survival. The effect of previous adaptation on $E$. coli starvation-survival, as assessed by plate counts and ${ }^{3} \mathrm{H}$-label decrease, was also observed in raw seawater. It seems from these data that the biological potential of $E$. coli cells suspended in sterile seawater has not been switched off or impaired seriously.
\end{abstract}

\section{Introduction}

The public health consequences of human pathogens in the aquatic environment have been recognized for over a century, and so studies of the survival of pathogens in aquatic systems are numerous (Anderson et al., 1983; Burton et al., 1987; García-Lara et al., 1991 b; Mason et al., 1986; Rhodes \& Kator, 1988). From the historic epidemiological study of cholera by Snow (1936) to the more recent studies after outbreaks of Legionnaire's disease (Broome, 1984), microbiologists have accumulated data on the survival and transmission of pathogens in water. More recently the issues concerning release of genetically engineered micro-organisms have further stimulated studies on bacterial survival.

In most studies, plate counts on selective or nonselective media have been the criteria used to assess

*Author for correspondence. Present address: Department of Microbiology, School of Medicine, University of Connecticut Health Center, 236 Farmington Ave., Farmington, Connecticut 06030-3205, USA. Tel. (203) 679 2203; fax (203) 6791239.

Abbreviations: EPA, exoproteolytic activity; ETS, electron transport system; MSD, minimum significant difference. survival, or mortality processes. However, we now know that bacteria can exist in other cellular states which may not be detected by plate counts, but they still retain metabolic activity or the capacity to grow (Munro et al., 1987). Various terms have been suggested to designate such cellular states. Non-culturable bacteria are cells that are incapable of producing visible colonies on plates, but show cellular elongation as a result of metabolic activity and growth (Roszak \& Colwell, 1987). Dormant or resting microbes are defined as having a temporary loss of viability which can be restored by incubation in appropriate conditions (Mason et al., 1986). Injured bacteria are those cells that become non-viable in selective media, but remain viable in standard media with no selective agents (McDonald et al., 1983; Rhodes \& Kator, 1988).

The survival of enteric bacteria in aquatic environments has been described in terms of temperature (Rhodes \& Kator, 1988), solar radiation (Barcina et al., 1986), the presence of toxins (Gurijala \& Alexander, 1990), nutrient starvation, osmotic stress (Kjelleberg et al., 1987; Munro et al., 1989; Sorensen, 1991), competition with the autochthonous microflora, predation by protozoa (García-Lara et al., 1991b; Rhodes \& 
Kator, 1988; Sorensen, 1991) and the presence of bacteriophages (García-Lara et al., 1991b) or lytic microflora (Gurijala \& Alexander, 1990). However, allochthonous bacteria react to starvation and stress in aquatic systems in many ways. Starvation enhances resistance to osmotic challenge, heat and oxidative shocks and disinfectant agents (Matin et al., 1989). In addition, growth of $E$. coli in marine medium or wastewater/seawater mixtures increases its resistance to bacteriophages, heavy metals and antibiotics and hence increases its survival in seawater (Chai, 1983; Munro et al., 1987). The synthesis of osmoprotectants is achieved by growing cells in high-osmolarity medium (Munro et al., 1987, 1989). Nutrient deprivation and/or osmotic stress increases protein turnover in $E$. coli and, with some substrates, high-affinity transport systems are induced (Gauthier et al., 1990; Kjelleberg et al., 1987; Matin et $a l .$, 1989). The expression and secretion of exoproteases is also increased at the onset of starvation in Vibrio and Pseudomonas (Albertson et al., 1990; Nyström et al., 1990). Catabolic enzymes are derepressed, to diversify the utilizable substrates. Non-growing bacteria produce inhibitors of cell wall synthesis that make the cells more resistant to autolysis (Kjelleberg et al., 1987). The DNA evolution of allochthonous bacteria confronting starvation or osmotic shock is less clear (Csonka, 1989; Kjelleberg et al., 1987; Matin et al., 1989; Nyström et al., 1990).

In this study we assess the influence of the adaptation of $E$. coli to seawater on its survival in seawater. Besides viable and microscopic counts, we monitored disappearance of radioactive label, electron transport system activity, thymidine incorporation, exoproteolytic activity and changes in cellular DNA content. Differences in viability and metabolic activities between adapted and non-adapted populations were observed.

\section{Methods}

Bacterial strain, media and growth conditions. E. coli 536, a naturally streptomycin $\left(1000 \mu \mathrm{g} \mathrm{ml}^{-1}\right)$ resistant strain, isolated from a human urinary tract infection (Berger et al., 1982) was employed in this study. The liquid media used to grow $E$. coli were: (i) Luria-Bertani broth (LB) (Miller, 1977); (ii) mineral medium 9 (Miller, 1977) supplemented with $0.2 \%(\mathrm{w} / \mathrm{v})$ glucose $(\mathrm{M} 9 \mathrm{G})$; (iii) artificial seawater medium ( $38 \mathrm{~g} \mathrm{l}^{-1}$; ADSA-Micro, Barcelona, Spain) supplemented with $0.05 \%$ Tryptone (L42, Oxoid), 0.05\% peptone (L37, Oxoid), $0.05 \%$ yeast extract (L21, Oxoid), at pH 7.8 (MAR). Cells used in starvationsurvival experiments were inoculated from an overnight $\mathrm{LB}$ culture at $30^{\circ} \mathrm{C}$ into $\mathrm{M} 9 \mathrm{G}$ and $\mathrm{MAR}$, and then progressively resubcultured five times into fresh media (M9G or MAR respectively). The cultures were incubated in the dark for $24 \mathrm{~h}$ in a shaking incubator (120 r.p.m.), at $20^{\circ} \mathrm{C}$ for the MAR medium cultures, and at $30^{\circ} \mathrm{C}$ for the M9G medium cultures.

Starvation-survival experiments. Seawater was collected from the natural beach at Barcelona, Spain (salinity $39 \mathrm{~g} \mathrm{l}^{-1}$, temperature $15^{\circ} \mathrm{C}$, $\mathrm{pH} 7 \cdot 6$ ). Sterile seawater was prepared by filtering through a $0.2 \mu \mathrm{m}$ filter (GSWP, Millipore) and autoclaving $\left(121^{\circ} \mathrm{C}, 15 \mathrm{~min}\right)$. Erlenmeyer flasks ( 2 litres) containing 1.2 litres of either raw or sterile seawater were used for the survival experiments. Cells were centrifuged (5000 r.p.m., $5 \mathrm{~min}, 20^{\circ} \mathrm{C}$ ), washed twice in M9G or MAR without nutrients, and then washed and resuspended in sterile seawater. Each Erlenmeyer flask was inoculated with the resulting cells to a final concentration of $10^{7}$ cells $\mathrm{ml}^{-1}$ and was incubated in the dark at $20^{\circ} \mathrm{C}$ with shaking (120 r.p.m.).

Viable and epifluorescence counts. The number of viable $E$. coli cells in the starvation-survival experiments was calculated from the number of colony-forming units on TSA (Tryptone soya agar, CM131, Oxoid) plates incubated for $48 \mathrm{~h}$ at $30^{\circ} \mathrm{C}$. Streptomycin $\left(500 \mu \mathrm{g} \mathrm{ml}^{-1}\right)$ was added to the plates for counts from raw seawater. The colonies were confirmed to be $E$. coli by replica plating onto eosin methylene blue agar (CM69, Oxoid) at $37^{\circ} \mathrm{C}$ overnight. Epifluorescence counts were made by a standard acridine orange staining method (Hobbie et al., 1977). However, polycarbonate filters (Nuclepore PC; $25 \mathrm{~mm}, 0.2 \mu \mathrm{m}$ ) were stained with Sudan black B (Merck) $\left[67 \mathrm{ml}^{-1}\right.$ in $50 \%(\mathrm{v} / \mathrm{v})$ ethanol for 18-24 h] and viewed with a Nikon epifluorescence microscope (Nikon Optiphot). Manual counting with quadrants was performed. Approximately 300 bacteria per filter were counted.

Preparation of ${ }^{3} \mathrm{H}$-labelled cells. ${ }^{3} \mathrm{H}$-labelled cells of $E$. coli were obtained by adding $100 \mathrm{nM}-\left[\right.$ methyl $\left.{ }^{3} \mathrm{H}\right]$ thymidine (specific activity 86-90 $\mathrm{Ci} \mathrm{mmol}^{-1} ; 3 \cdot 18-3.33 \mathrm{TBq} \mathrm{mmol}^{-1}$; Amersham): final concentration in the last subculture in either MAR or M9G. The disappearance of cold TCA-insoluble label was monitored during starvation-survival and this was used as an estimation of the cell mortality in the E. coli population (García-Lara et al., 1991 b; Martínez, et al., 1989; Paszko-Kolva et al., 1991).

Cellular DNA content. The DNA content was estimated by the fluorimetric method described by Paul \& Myers (1982) using the dye Hoechst 33258 . Samples $(15-30 \mathrm{ml})$ from the flasks containing sterile seawater, and either adapted or non-adapted cells, were collected on cellulose acetate filters ( $25 \mathrm{~mm}, 0 \cdot 2 \mu \mathrm{m}$; Sartorius) and the filters kept at $-20^{\circ} \mathrm{C}$. The DNA was extracted from the filters by sonication (Braun Labsonic 1510) and the fluorescence was immediately measured (Hitachi F-2000 fluorescence spectrophotometer).

$\left[\right.$ methyl $\left.-{ }^{3} H\right]$ Thymidine incorporation. The rate of $\left[\right.$ methyl $\left.-{ }^{3} \mathrm{H}\right]$ thymidine incorporation by $E$. coli surviving in the sterile seawater was measured according to the method of Fuhrman \& Azam (1982) by adding $20 \mathrm{nM}-\left[\right.$ methyl $\left.^{-3} \mathrm{H}\right]$ thymidine (specific activity $80-90 \mathrm{Ci} \mathrm{mmol}^{-1}$; 2.96-3.33 TBq mmol ${ }^{-1}$; Amersham) (final concentration) to $3 \mathrm{ml}$ sample, and incubating for $1 \mathrm{~h}$ at $20^{\circ} \mathrm{C}$. These conditions ensured linearity of thymidine incorporation (Martínez, 1989). The cold TCAinsoluble fraction was collected on $0.2 \mu \mathrm{m}$ cellulose acetate filters (Sartorius), and the $\left[\right.$ methyl $\left.^{-3} \mathrm{H}\right]$ thymidine incorporated was estimated by liquid scintillation counting.

Electron transport system (ETS) activity. This was assayed by the reduction of 2-( $p$-iodophenyl)-3-( $p$-nitrophenyl)-5-phenyltetrazolium chloride (INT), using the following assay conditions. Microbial biomass from filtered and autoclaved seawater was harvested by filtration $(15-50 \mathrm{ml})$ on cellulose acetate membrane filters, $0.2 \mu \mathrm{m}$ pore size. The filters were resuspended in $1 \mathrm{ml} 50 \mathrm{~mm}$-phosphate buffer containing $75 \mu \mathrm{M}-\mathrm{MgSO}_{4}, 80 \mathrm{~mm}$-sodium succinate, $0.85 \mathrm{~mm}-\mathrm{NADH}$ and $0.24 \mathrm{~mm}-\mathrm{NADPH}$. Toluene $(10 \mu \mathrm{l})$ and $0.1 \%(\mathrm{v} / \mathrm{v})$ sodium deoxycholate solution $(20 \mu \mathrm{l})$ were added to make the cells permeable. The mixture was incubated in a shaking incubator for $20-30 \mathrm{~min}$ at $37^{\circ} \mathrm{C}$. Once the permeabilization was complete, $200 \mu 140 \mathrm{mM}$-INT was added and incubated $\left(20^{\circ} \mathrm{C}\right.$, dark, 5-60 min). Formazan was assayed by adding $3 \mathrm{ml}$ acetone $(100 \%, \mathrm{v} / \mathrm{v})$, and shaking continuously overnight at $20^{\circ} \mathrm{C}$ in capped tubes. The resulting suspension was centrifuged ( 4000 r.p.m., $10 \mathrm{~min}, 20^{\circ} \mathrm{C}$ ). The $A_{460}$ of the supernatant was determined. The blank for these measurements contained all 
components of the assay, except the sample. The activity was calculated as the formazan produced $\left(\mu \mathrm{mol}^{-1} \mathrm{~h}^{-1}\right)$ with reference to a calibration curve of 2.75-150 $\mu \mathrm{M}$-formazan (Fluka) $(y=45.42 x+0.056 ; r=0.996)$ (García-Lara et al., 1991 a).

Exoproteolytic activity $(E P A)$. This was assayed spectrofluorimetrically (Hitachi F-2000 fluorescence spectrophotometer; excitation $338 \mathrm{~nm}$, emission $410 \mathrm{~nm}$ ) by following the appearance of fluorescent $\beta$ naphthylamine after the addition of $1 \mathrm{mM}$-L-leucyl- $\beta$-naphthylamide to the sample (Somville \& Billen, 1983). The assessment of total EPA was made from the flasks with sterile seawater containing $E$. coli. Cell-free activity was assessed after removing the cells by filtration through $0.2 \mu \mathrm{m}$ filters. The difference between the total and cell-free EPA gave the cell-attached activity. The activity was calculated as $\beta$-naphthylamine produced $\left(\mathrm{nmol} \mathrm{l}^{-1} \mathrm{~h}^{-1}\right)$, calibrated over the range $2 \cdot 75-150 \mu \mathrm{M}$ $\beta$-naphthylamine (Fluka) $(y=0.66 x+44.9 ; r=0.999)$.

Reproducibility of the results. Results are presented as mean values from three independent experiments. Homogeneity of variance was shown using Bartlett's test, the minimum significant difference (MSD) was calculated by the Tukey-Kramer method, and differences between groups of means by the sum of squares simultaneous test procedure (SS-STP) (Sokal \& Rohlf, 1981). Analysis of variance, covariance and regression were performed with Minitab (Cle. Com Ltd., Birmingham, UK). The significance of the differences in the slopes between the adapted and non-adapted populations was determined by covariance analysis, being considered significantly different at $P<0.05$.

\section{Results}

Viable counts, epifluorescence counts, ${ }^{3} \mathrm{H}$-label and cellular DNA content during survival

In sterile seawater, viability of $E$. coli populations grown in M9G (non-adapted population) and MAR (adapted population) was significantly different (Fig. 1). E. coli grown in MAR did not show a significant decrease in colony forming units per $\mathrm{ml}$ during starvation-survival experiments. In contrast, there was a clear reduction in the viable counts of the non-adapted $E$. coli. Significant differences, determined by analysis of covariance, were not observed between the viable counts on TSA or TSA plus streptomycin from the sterile flasks during the survival experiments. No resistant bacteria were detected in the natural sample at the streptomycin concentration used (data not shown).

Both populations maintained significantly constant epifluorescence counts (Fig. $2 a$ ) and amount of ${ }^{3} \mathrm{H}$-label (Fig. $2 b$ ) during survival in sterile seawater, despite the difference in viability between adapted and non-adapted populations (Table 1). Cellular DNA concentration in adapted and non-adapted cells increased significantly (analysed by SS-STP) during the first $5 \mathrm{~d}$ and was subsequently maintained (Fig. 3), although no significant increase was observed in epifluorescence counts.

$E$. coli plate counts and the amount of ${ }^{3} \mathrm{H}$-label in raw seawater declined in all the experiments (Figs 1 and $2 b$ ). Although the mortality in the raw seawater was higher than that in the sterile seawater, the difference in plate counts between the adapted and non-adapted population was still evident (Fig. 1). In raw seawater, the adapted and non-adapted $E$. coli also showed an equivalent decrease in ${ }^{3} \mathrm{H}$-label, although the decline was not as large as that obtained from the plate counts (Table 1).

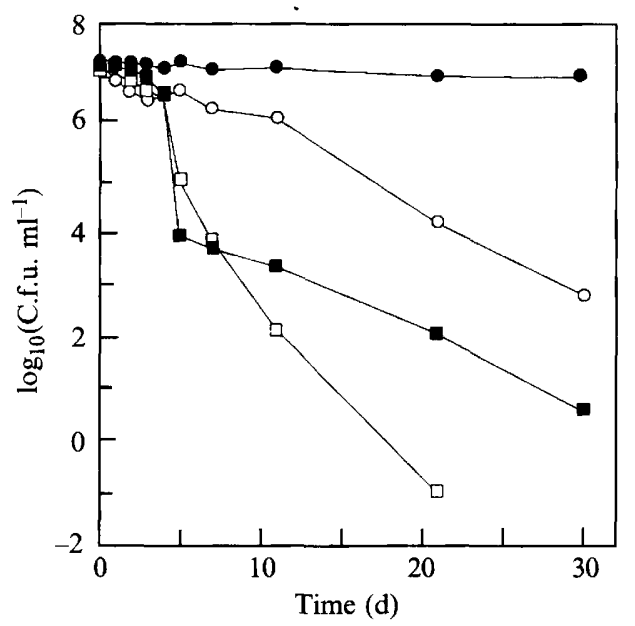

Fig. 1. Survival of adapted $(\boldsymbol{O}, \boldsymbol{\square})$ and non-adapted $(O, \square)$ E. coli in sterile $(\bullet, O)$ and raw $(\square, \square)$ seawater determined by plate counts.

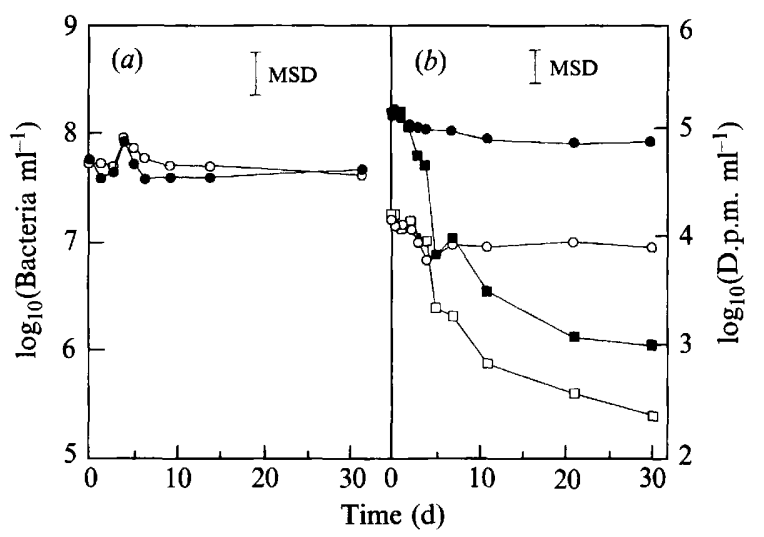

Fig. 2. Epifluorescence counts $(a)$ and ${ }^{3} \mathrm{H}$-label decrease $(b)$ of the adapted $(\boldsymbol{O}, \square)$ and non-adapted $(\bigcirc, \square)$ E. coli during starvationsurvival in sterile $(\boldsymbol{O}, O)$ and raw $(\square, \square)$ seawater.

Table 1. Mortality rates of adapted and non-adapted E. coli 536 during survival in sterile and raw seawater

Slopes were calculated from linear regression of log data of plate and epifluorescence counts and amount of radioactive label with respect to time. Mortality rates were estimated from these slopes.

\begin{tabular}{|c|c|c|c|c|c|}
\hline \multirow[b]{3}{*}{$\begin{array}{l}E \text {. coli } \\
\text { population }\end{array}$} & \multicolumn{5}{|c|}{$10^{3} \times$ Mortality rates $\left(\mathrm{h}^{-1}\right)$ in: } \\
\hline & \multicolumn{3}{|c|}{ Sterile seawater } & \multicolumn{2}{|c|}{ Raw seawater } \\
\hline & $\begin{array}{l}\text { Viable } \\
\text { counts }\end{array}$ & $\begin{array}{l}\text { Microscopic } \\
\text { counts }\end{array}$ & ${ }^{3} \mathrm{H}$-label & $\begin{array}{l}\text { Viable } \\
\text { counts }\end{array}$ & ${ }^{3} \mathrm{H}$-label \\
\hline Adapted & 0.79 & 0.67 & 0.93 & $27 \cdot 14$ & $7 \cdot 16$ \\
\hline Non-adapted & 5.93 & $1 \cdot 12$ & 0.65 & $29 \cdot 07$ & $6 \cdot 40$ \\
\hline
\end{tabular}




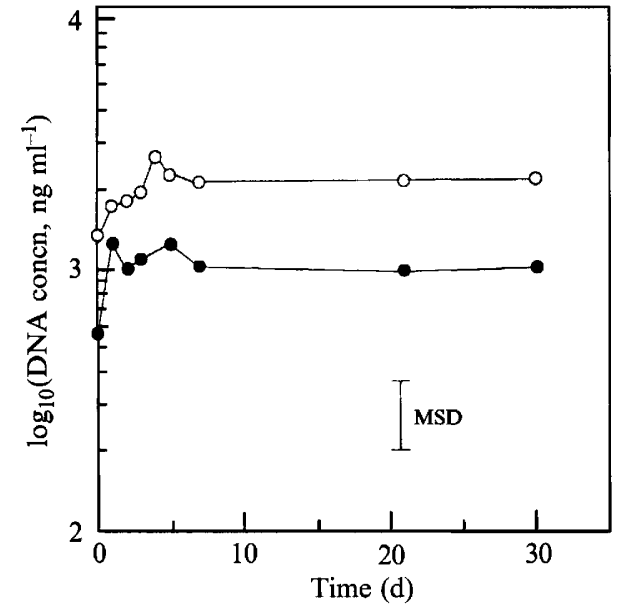

Fig. 3. Cellular DNA determinations in adapted (O) and non-adapted (O) E. coli during starvation-survival in sterile seawater.

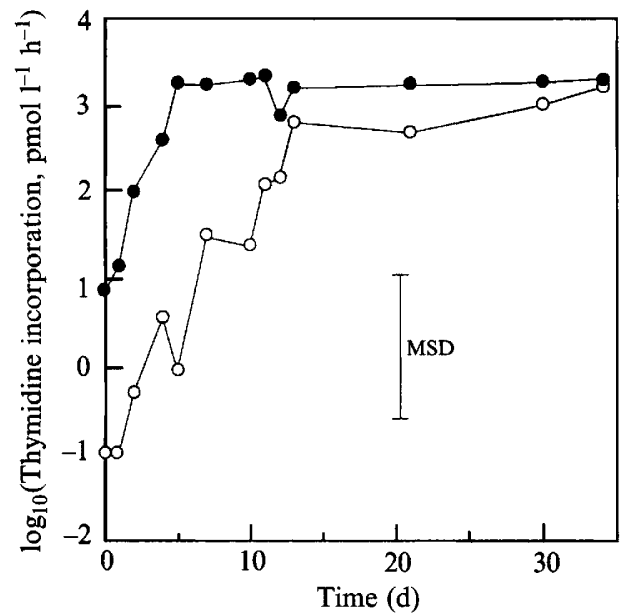

Fig. 4. $\left[{ }^{3} \mathrm{H}\right]$ Thymidine incorporation activity in adapted (O) and nonadapted (O) E. coli populations during starvation-survival in sterile seawater.

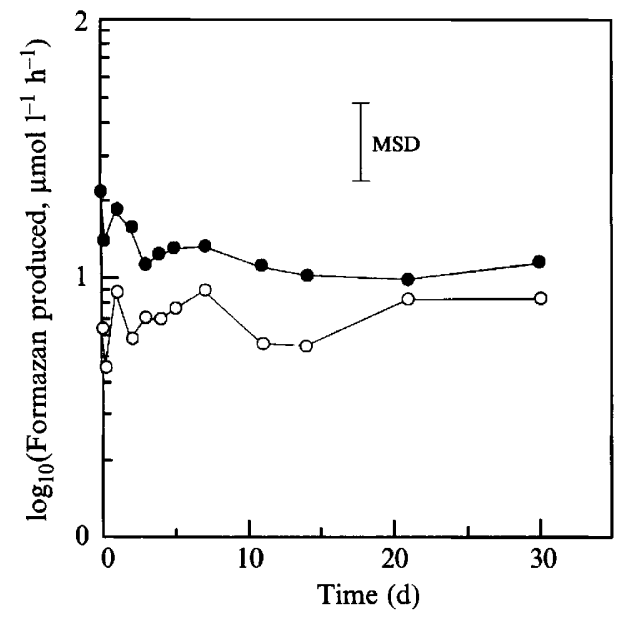

Fig. 5. ETS activity of adapted (O) and non-adapted (O) E. coli populations during starvation-survival in sterile seawater.

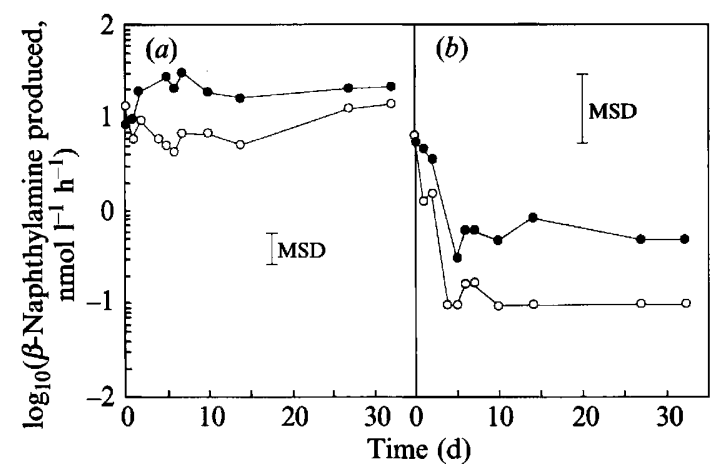

Fig. 6. Cell-attached $(a)$ and cell-free $(b)$ EPA in adapted $(\bullet)$ and nonadapted $(O)$ E. coli populations during starvation-survival in sterile seawater.

\section{Metabolic activity determinations}

A significant increase and subsequent plateau in [methyl${ }^{3} \mathrm{H}$ ]thymidine incorporation during starvation-survival was observed in adapted and non-adapted cells (Fig. 4). Thymidine incorporation in the two populations increased at similar rates, reaching equivalent levels. However, the initial value for the adapted cells was significantly higher than that for non-adapted cells. As for thymidine incorporation, the ETS activity of adapted $E$. coli was significantly higher than that of non-adapted $E$. coli at the onset of starvation-survival in sterile seawater (Fig. 5). The ETS activity remained constant during the survival of both populations. Cell-attached EPA of the adapted population increased and was subsequently maintained during starvation-survival in sterile seawater (Fig. 6). In contrast, an initial significant decrease and subsequent increase in cell-attached EPA of the non-adapted population was observed. In both populations the cell-free EPA steadily decreased to very low values.

\section{Discussion}

Some authors have reported that $E$. coli can multiply in natural waters in the absence of autochthonous microflora, and that the extent of this growth is dependent upon the nutrient concentration (Chai, 1983; Dawe \& Penrose, 1978; Gerba \& McLeod, 1976; Sorensen, 1991). Conversely, other authors have suggested that coliforms are not killed by sea water but are debilitated to the extent that they will not form colonies on solid media (Amy \& Hiatt, 1989; Dawe \& Penrose, 1978; Munro et al., 1989; Roth et al., 1988). The $E$. coli populations we used, did not show differences in growth on TSA or TSA supplemented with streptomycin. Hence the sublethal injury caused by stress did not affect their ability to form colonies on plates in the presence of the antibiotic. Other 
workers have reported similar effects (Gurijala \& Alexander, 1988, 1990; Roth et al., 1988).

A high percentage of the cells starved in sterile seawater after growth in M9G did not yield colonies on plates, although they were observed by epifluorescence microscopy (Figs 1 and $2 a$ ). The difference between the plate counts and the epifluorescence counts may be attributed to cells that survived but were unable to replicate on plates (Roszak \& Colwell, 1987) due to starvation (Kjelleberg et al., 1987), osmotic shock, the presence of toxic thermostable compounds or temperature stress (Dawe \& Penrose, 1978; Gauthier et al., 1988; Gurijala \& Alexander, 1990; Roth et al., 1988). We found that while the viable counts decreased, the epifluorescence counts, the ${ }^{3} \mathrm{H}$-labelling, metabolic activities and cellular DNA remained stable or increased. This suggests that most of the non-viable cells were metabolically active. The decay in viable count and ${ }^{3} \mathrm{H}-$ labelling in raw seawater (Figs 1 and $2 b$ ) confirmed the well-documented phenomenon of coliform mortality in seawater, mainly caused by the autochthonous microflora (Chamberlin \& Mitchell, 1978; García-Lara et al., $1991 b$; Martínez et al., 1989). Mortality of the nonadapted population, assessed by the decrease in ${ }^{3} \mathrm{H}$-label, was not as high as that estimated by plate counts, in either sterile or raw seawater (Table 1). The difference between viable and ${ }^{3} \mathrm{H}$-label determinations could be attributed to morphologically, metabolically and genetically intact bacteria, which were nonculturable, as some authors have suggested (García-Lara et al., 1991b). These data are in accordance with previous reports mentioning that ATP, DNA and RNA did not decline during E. coli starvation (Csonka, 1989; Morgan, et al., 1991; Moyer \& Morita, 1989). It seems that the starved cells present a greater biological potential than could be deduced from plate counts. The increase in cellular DNA content without an increase in cell numbers in $E$. coli during starvation-survival is in accordance with data from previous studies (Brdar et al., 1965). Nevertheless, an increase in cell numbers by fragmentation accompanying an increase in cellular DNA has also been shown (Nyström \& Kjelleberg, 1989).

Although the thymidine incorporation could be due to DNA replication, the high values achieved could also be attributed to the utilization of thymidine as a carbon source (Servais et al., 1987). In addition, the rapid increase in thymidine incorporation in adapted and nonadapted populations continued when no increase in the cellular DNA content was observed (Figs 3 and 4). Perhaps net increase of cellular DNA concentration was not detected because of similar rates of DNA synthesis and DNA degradation (Mårdén et al., 1988). The utilization of thymidine as a carbon source would support the idea that death (measured as reduction in viable counts) during starvation and osmotic shock involves the de novo synthesis of new proteins, which makes the cell more efficient at scavenging nutrients and gives a more stress-resistant phenotype (Matin et al., 1989; Matin, 1990). Related to this issue, the adapted $E$. coli showed higher thymidine incorporation activity at the onset of starvation-survival, at levels similar to those detected in the marine environment (Martínez, 1989).

Therefore, high-affinity transport systems and/or activation of biochemical pathways involved in thymidine metabolism could be positively affected by seawater stress. However, we can not rule out that the surviving cells could show cryptic growth, supported by contaminating nutrients in the sterile seawater used or from cellular leakage or lysis (Gauthier et al. 1990; Matin et al. 1989). Since we have tested the cumulative effects of three different variables (salinity, nutrients and temperature) during preadaptation, the mechanism by which preadaptation affects the ability to recover cells by plate count methods is unknown. Whether it is the contribution of a single condition, or the combination of all three in the preadaptation that allows for the high viability during subsequent starvation is of general physiological interest.

EPA was demonstrated for $E$. coli over more than one month of starvation-survival in sterile seawater. Cellattached EPA increased in the starvation flask containing the adapted $E$. coli, as has been reported for marine Vibrio isolates (Albertson et al., 1990). In contrast, the non-adapted $E$. coli reduced its cell-attached EPA from the onset of starvation-survival. Thus, seawater-adapted enteric bacteria may develop physiological shifts similar to marine bacteria to help their survival in marine environments. It is possible that non-adapted enteric bacteria are not as sensitive as adapted bacteria to changes in nutrient limitation, and therefore are less able to modify their EPA. Cell-free EPA is drastically reduced in both populations during starvation-survival in sterile seawater. Low cell-free EPA values are normal in natural aquatic environments (Somville \& Billen, 1983; Vives-Rego et al., 1985).

By the end of the experiment, the non-adapted population in the sterile seawater showed a large reduction in plate counts. However, ETS and EPA remained constant, and thymidine incorporation rate was substantially higher (Figs 1, 5 and 6). This indicates that allochthonous bacteria not detected by plate counts may still play an important role in the nitrogen and carbon flow in aquatic environments (Gauthier et al., 1990; Nyström et al., 1990).

By comparison with the non-adapted population the maintenance of viability of the adapted population, and its high initial metabolic activities, agrees with a previous theory (Munro et al., 1989) to explain the stress-enhanced 
resistance of cells preadapted to marine environments. These cells already express some of the essential metabolic functions needed to confront the new environment, and do not need to make drastic cellular changes, as do non-adapted populations.

We conclude that when $E$. coli cells are subjected to seawater stress, the observed decline in cell viability, indicated by the colony-forming ability on solid media, overestimates the real death or lysis rate. Biomass and metabolic activity estimations indicate that $E$. coli survives to a greater extent than the colony counts show. $E$. coli cells adapted to seawater survive better in marine environments than non-adapted cells. The different fates of $E$. coli in raw and sterile sea water may indicate that its disappearance is principally caused by grazing of protozoa, bacteriolytic populations and/or other thermosensitive agents. In addition gene expression and DNA replication could still be actively working when $E$. coli survives in the marine environment.

We thank John C. Fry, Martin J. Day, Haydn G. Williams and Caroline D. Perkins for critical review of the manuscript.

\section{References}

Albertson, N. H., Nyström, T. \& KJelleberg, S. (1990). Exoprotease activity of two marine bacteria during starvation. Applied and Environmental Microbiology 56, 218-223.

Амy, P. S. \& Hiatr, H. D. (1989). Survival and detection of bacteria in aquatic environments. Applied and Environmental Microbiology 55, $788-793$.

Anderson, I. C., Rhodes, M. \& Kator, H. I. (1983). Seasonal variation in survival of Escherichia coli exposed 'in situ' in membrane diffusion chambers containing filtered and non-filtered estuarine waters. Applied and Environmental Microbiology 45, 1877-1883.

Barcina, I., Arana, I., Iriberri, J. \& EgEA, L. (1986). Influence of light and natural microbiota of the Butron River on E. coli survival. Antonie van Leeuwenhoek 52, 555-566.

Berger, H., Hacker, J., Juarez, A., Hughes, C. \& Goebel, W. (1982). Cloning of the chromosomal determinants encoding hemolysin production and mannose-resistant hemoagglutination in Escherichia coli. Journal of Bacteriology 152, 1241-1247.

Brdar, B., Kos, E. \& Drakulic, M. (1965). Metabolism of nucleic acids and protein in starving bacteria. Nature, London 208, 303-304.

BROOME, C. V. (1984). Current issues in epidemiology of legionellosis, 1983. In Legionella: Proceedings of the 2nd International Symposium, pp. 205-209. Edited by C. Thornsberry and others. Washington, DC: American Society for Microbiology.

Burton, G. A., Gunnison, D. \& Lanza, G. R. (1987). Survival of pathogenic bacteria in various freshwater sediments. Applied and Environmental Microbiology 53, 633-638.

CHAI, T. (1983). Characteristics of Escherichia coli grown in bay water as compared with rich medium. Applied and Environmental Microbiology 45, 1316-1323.

Chamberlin, C. E. \& Mrtchell, R. (1978). A decay model for enteric bacteria in natural waters. In Water Pollution Microbiology, pp. 325-348. Edited by R. Mitchell. New York: John Wiley.

CsonKa, L. (1989). Physiological and genetic response of bacteria to osmotic stress. Microbiological Reviews 53, 121-147.

DaWE, L. L. \& PENRose, W. R. (1978). 'Bactericidal' property of seawater: death or debilitation? Applied and Environmental Microbiology 35, 829-833.

FunRman, J. \& AZAM, F. (1982). Bacterioplankton secondary production estimates for coastal waters of British Columbia, Antarctica and California. Applied and Environmental Microbiology 39, 10851095.

García-lara, J., Penon, F. J., González, J. \& Vives-Rego, J. $(1991 a)$. Assessment of microbial activity by the int-dehydrogenase assay during the degradation of linear alkylbenzene sulfonate (LAS) in sea water and in the O.E.C.D. screening test method. Biomedical Letters 46, 151-157.

García-lara, J., Menon, P., Servais, P. \& Billen, G. (1991 b). Mortality of fecal bacteria in seawater. Applied and Environmental Microbiology 57, 885-888.

Gauthier, M. J., Munro, P. M. \& Breittmayer, V. A. (1988). Influence of prior growth conditions on low nutrient response of Escherichia coli in seawater. Canadian Journal of Microbiology 35, 379-383.

Gauthier, M. J., Flatau, G. N. \& Clément, R. L. (1990). Influence of phosphate ions and alkaline phosphatase activity of cells on survival of Escherichia coli in seawater. Microbial Ecology 20, 245-251.

GeRBA, C. P. \& MCLeOD, J. S. (1976). Effects of sediments on the survival of E. coli in marine waters. Applied and Environmental Microbiology 32, 114-120.

Gurijala, K. R. \& Alexander, M. (1988). Role of sublethal injury in decline of bacterial populations in lake water. Applied and Environmental Microbiology 54, 2859-2861.

Gurijala, K. R. \& Alexander, M. (1990). Explanation for the decline of bacteria introduced into lake water. Microbial Ecology 20, 231-244.

Hobbie, J., Daley, R. J. \& JASPER, S. (1977). Use of Nuclepore filters for counting bacteria by fluorescence microscopy. Applied and Environmental Microbiology 33, 1225-1228.

KJelleberg, S., Hermansson, M. \& MÅrdÉN, P. (1987). The transient phase between growth and nongrowth of heterotrophic bacteria, with emphasis on the marine environment. Annual Review of Microbiology 41, 25-49.

McDonald, L. C., Hackney, C. R. \& Bray, B. (1983). Enhanced recovery of injured Escherichia coli by compounds that degrade hydrogen peroxide or block its formation. Applied and Environmental Microbiology 45, 360-365.

MÅRdÉn, P., HeRmansson, M. \& KJelleberg, S. (1988). Incorporation of tritiated thymidine by marine bacterial isolates when undergoing a starvation survival response. Archives of Microbiology 149, 427-432.

MarTíneZ, J. (1989). Activity and mortality of bacteria in aquatic systems: basic and applied aspects. $\mathrm{PhD}$ thesis, University of Barcelona, Spain.

MartíneZ, J., García-LaRA, J. \& Vives-Rego, J. (1989). Estimation of Escherichia coli mortality in seawater by the decrease in ${ }^{3} \mathrm{H}$-label and electron transport system activity. Microbial Ecology 17, 219-225.

Mason, C. A., Hamer, G. \& BRYers, J. D. (1986). The death and lysis of microorganisms in environment processes. FEMS Microbiology Reviews 39, 373-401.

Matin, A. (1990). Molecular analysis of the starvation stress in Escherichia coli. FEMS Microbiology Ecology 74, 185-196.

Matin, A., Auger, E. A., Blum, P. H. \& Schultz, J. E. (1989). Genetic basis of starvation survival in nondifferentiating bacteria. Annual Review of Microbiology 43, 293-316.

MilleR, J. H. (1977). Experiments in Molecular Genetics, p. 431. Cold Spring Harbor, NY: Cold Spring Harbor Laboratory.

Morgan, J. A. W., Cranwell, P. A. \& Pickup, R. W. (1991). Survival of Aeromonas salmonicida in lake water. Applied and Environmental Microbiology 57, 1777-1782.

MOYeR, C. L. \& Morita, R. Y. (1989). Effect of growth rate and starvation-survival on cellular DNA, RNA, and protein of psychrophilic marine bacterium. Applied and Environmental Microbiology 55, 2710-2716.

Munro, P. M., Gauthier, M. J. \& Laumond, F. M. (1987). Changes in Escherichia coli cells starved in seawater or grown in seawaterwaste water mixtures. Applied and Environmental Microbiology 53, 1476-1481.

Munro, P. M., Gauthier, M. J., BrettTmayer, V. A. \& Bongiovanni, J. (1989). Influence of osmoregulation processes on starvation survival of Escherichia coli in seawater. Applied and Environmental Microbiology 55, 2017-2024. 
NySTRÖM, T. \& KJELLEBERG, J. (1989). Role of protein synthesis in the cell division and starvation induced resistance to autolysis of a marine Vibrio during the initial phase of starvation. Journal of General Microbiology 135, 1599-1606.

NyStRöM, T., Albertson, N. H., FlårdH, K. \& KJelleberg, S. (1990). Physiological and molecular adaptation to starvation and recovery from starvation by the marine Vibrio sp. S14. FEMS Microbiology Ecology 74, 129-140.

Paszko-Kolva, C., Shahamat, M., Yamamoto, H., Sawyer, T., VIVES-REGo, J. \& Colwell, R. R. (1991). Survival of Legionella pneumophila in the aquatic environment. Microbial Ecology 22, 75-83.

PAUL, J. H. \& MYERs, B. (1982). Fluorometric determination of DNA in aquatic microorganisms by use of Hoechst 33258. Applied and Environmental Microbiology 43, 1393-1399.

RHODES, M. W. \& KATOR, H. I. (1988). Survival of Escherichia coli and Salmonella spp. in estuarine environments. Applies and Environmental Microbiology 54, 2902-2907.

RosZAK, D. B. \& ColWELL, R. R. (1987). Survival strategies of bacteria in the natural environmental. Microbiological Reviews 51, 365-379.
Roth, W. G., LeCKIE, M. P. \& DietzleR, D. N. (1988). Restoration of colony-forming activity in osmotically stressed Escherichia coli by betaine. Applied and Environmental Microbiology 54, 3142-3146.

Servais, P., Martínez, J., Billen, G. \& Vives-Rego, J. (1987). Determining $\left[{ }^{3} \mathrm{H}\right]$-thymidine incorporation into bacterioplankton DNA: improvement of the method by DNase treatment. Applied and Environmental Microbiology 53, 1977-1979.

SNow, J. (1936). On the Mode of Communication of Cholera. Hafner, New York: Commonwealth Fund.

SoKAL, R. R. \& Rohlf, F. J. (1981). Biometry. New York: W. H. Freeman \& Co.

Somville, M. \& Billen, G. (1983). A method for determining exoproteolytic activity in natural waters. Limnology and Oceanography 28, 190-193.

SORENSEN, S. J. (1991). Survival of Escherichia coli K12 in seawater. FEMS Microbiology Ecology 85, 161-168.

Vives-Rego, J., Billen, G. \& Fontigny, A. (1985). Free and attached proteolytic activity in water environments. Marine Ecology Progress Series 21, 245-249. 